УДК 378.147

DOI:

\begin{abstract}
Оксана Гутиряк, кандидат філологічних наук, доцент кафедри мовної та міжкультурної комунікації Дрогобииького державного педагогічного університету імені Івана Франка

Оксана Павлішак, кандидат педагогічних наук, доцент кафедри мовної та міжкультурної комунікачії

Дрогобицького державного педагогічного університету імені Івана Франка
\end{abstract}

\title{
ДІЛОВА ГРА ЯК МЕТОД АКТИВНОГО НАВЧАННЯ МАЙБУТНІХ ФАХІВЦІВ
}

У статті проаналізовано особливості ділової гри як методу активного навчання у закладах вищоі освіти. Доведено, що з допомогою иього методу навчання можна ефективно формувати уміння, навички та професійно-значущі якості особистості майбутнього фахівия. Подано характерні ознаки ділових ігор. Визначено педагогічні умови використання ділових ігор на заняттях у вищій школі. Наведено вимоги щэодо проектування та застосування ділових ігор у практичній роботі викладачів закладів вищої освіти.

Ключові слова: ділова гра; активне навчання; метод навчання; підготовка майбутніх фахівиів.

Jim. 6.

Oksana Hutyryak, Ph.D.(Philology), Associate Professor of the Lingual and Intercultural Communication Department, Drohobych Ivan Franko State Pedagogical University

Oksana Pavlishak, Ph.D.(Pedagogy), Associate Professor of the Lingual and Intercultural Communication Department, Drohobych Ivan Franko State Pedagogical University

\section{BUSINESS GAME AS A METHOD OF ACTIVE TEACHING OF FUTURE SPECIALISTS}

The article deals with the peculiarities of a business game as a method of active teaching in higher educational establishments. The core and functions of active methods of teaching have been determined. It has been stated that active methods of teaching allow to develop the students mentality, to expand and deepen the professional knowledge, to develop practical skills and abilities, to intensify the educational process and to develop the ability to reflex. The classification of teaching methods (non-imitative (problematic lecture, problematic active-practical or laboratory lesson, individual course and graduation project, practice-internship, active group olympiads, olympiads etc), imitative (no playing and playing)) has been given. The core of the business game as a method of active teaching (a new branch of activity, an imitative experiment and a form of role teaching, research and solving educational problems) has been determined. The characteristic features of business games (a problem, a goal and objective existence; time reduction on professional skills learning, the abilities' and skills' development; distribution and playing roles; existence of situations that are solved gradually, several situations, several stages of a game; development of the independent students' decisions; existence of motivation system; taking into consideration possible obstacles etc) have been shown. The advantages of business games as a method of teaching (reduction of time on accumulation of professional experience, experimentation potential, the formation of integrated idea of professional activity of future specialists, the possibility of gaining social experience by students, the increase of interest to learning etc) were determined. Pedagogical conditions of use of business games at the lessons in a higher school (to include a playing activity into training of future specialists during the whole period of study; to provide the complex character of business games; to provide the realistic contents of business games etc) have been determined. The examples of use of business games and a project method in a practical work of teachers of higher educational establishments (justified use of business games, sufficient professional skills of a teacher, sufficient independence and freedom of the student's actions in the process of the game, observance of optimal duration of a business game etc) have been provided.

Keywords: a business game; an active teaching; teaching methods; a training of future specialists.

П остановка проблеми. У сучасних умовах конкурентного середовища змінюються вимоги до підготовки майбутніх фахівців. Випускники закладів вищої освіти сьогодні повинні вміти творчо підходити до розв'язання професійних завдань, бути готовими регулярно змінювати не лише умови праці, але й місце праці та вид виконуваної роботи.
Виникла пряма залежність між якісними показниками підготовки фахівця, його працевлаштуванням і наступною професійною кар'єрою. 3 огляду на це у процесі створення моделі майбутнього фахівця передбачається використання таких методів навчання, які б сприяли ефективному розвитку наявних у студентів здібностей і формуванню навичок 


\section{ДІЛОВА ГРА ЯК МЕТОДАКТИВНОГО НАВЧАННЯ МАЙБУТНІХ ФАХІВЦІВ}

самостійності, системності мислення та гнучкості.

Принаймні частково розв'язання цієї проблеми можливе шляхом застосування активних методів навчання. На відміну від традиційних, активні методи навчання дають змогу формування професійні уміння, модулювати зміст самостійної роботи, переорієнтовуючи навчальний процес із засвоєння інформації на самостійну творчу діяльність.

Аналіз останніх досліджень і публікацій. У дидактиці теорія методів навчання представлена працями Ю. Бабанського, М. Данилова, І. Лернера, М. Махмугова, М. Скаткіна та ін.

Загальні правила конструювання, організації і проведення ділових ігор обгрунтовували А. Вербицький, І. Куліш, П. Підласистий, I. Ситник, О. Хоменко, П. Щербань та ін. Зокрема, О. Хоменко вважає, що ділова гра $є$ одним 3 найперспективніших шляхів підвищення ефективності навчального процесу у вищій школі. При цьому ділова гра, на його переконання, $є$ змодельованою та педагогічно організованою діяльністю (навчально-пізнавальною, науководослідницькою, професійно-виробничою), яка забезпечує формування соціального та професійного досвіду особистості [6, 9 - 10]. А. Вербицький переконаний, що ділова гра - це особливий тип прилучення фахівця до майбутньої професійної діяльності [2].

Мета статті полягає в обгрунтуванні особливостей ділової гри як активного методу навчання у вищій школі.

Виклад основного матеріалу. В сучасній педагогіці обгрунтовується важливість і необхідність використання активних методів навчання. Це викликано насамперед сучасною ідеологією навчання, яка декларує визнання учня/ студента суб'єктом навчальних впливів. Активні методи дають змогу студентові розкрити особистісний потенціал, ще в студентській аудиторії набути професійних умінь та навичок, оскільки передбачають залучення майбутніх фахівців до розв'язання проблем, максимально наближених до професійної діяльності.

Активні методи навчання дозволяють:

- розвивати мислення студентів;

- розширювати і поглиблювати професійні знання, розвивати практичні уміння та навички;

- активізувати навчальний процес, спонукаючи студентів до творчої участі в ньому i забезпечуючи розвиток i саморозвиток особистості студента на основі виявлення його індивідуальних особливостей;

- розвивати вміння рефлексувати, що дає змогу студентам відшукати індивідуальний стиль професійної діяльності, досягти адекватної професійно-особистісної самооцінки, прогнозувати та аналізувати результати власної діяльності, підвищити рівень самоорганізації [3, 77 - 78].

Активні методи навчання поділяють на неімітаційні та імітаційні.

Неімітаційні охоплюють проблемну лекцію, проблемне активно-практичне чи лабораторне заняття, самостійне курсове та дипломне проектування, практику-стажування, активногрупові олімпіади, олімпіади тощо. Спільною характеристикою методів цієї групи є їхня орієнтованість на проблемність, інтенсифікацію пізнавальної діяльності студентів, проте водночас відсутність імітації реальних обставин в умовній ситуації.

Імітаційні методи, своєю чергою, поділяються на неігрові та ігрові.

До неігрових належать метод конкретних ситуацій, імітаційні вправи на знаходження розв'язку проблеми, тренінг. Їхня сутність полягає в моделюванні реальних об'єктів і ситуацій поза вільною грою та виконанням рольових функцій.

До ігрових належать ділові ігри, рольові ігри. Суттєва відмінність цих методів полягає в тому, що вони базуються на ігровій основі.

Виділяють різні види ігор, що використовуються з ігровою метою: дидактичні, імітаційні, рольові, організаційно-діяльнісні, операційні, ділові, управлінські, інноваційні тощо.

Великим дидактичним потенціалом характеризуються ділові ігри. Як нову галузь діяльності, імітаційний експеримент та форму рольового навчання, дослідження і розв'язання освітніх і виховних завдань розглядають цей тип ігор Ю. Арутюнов, Н. Борисова, С. Колесніченко [1].

Ділова гра поєднує в собі навчальний i професійний компоненти. Знання і вміння у ній засвоюються студентом не абстрактно, а в контексті конкретної професійної ситуації. Разом iз професійними знаннями майбутній фахівець набуває спеціальну компетенцію, зокрема: навички спеціальної взаємодії і управління людьми, вміння керувати і підпорядковуватися, а отже така гра виховує й особистісні якості.

Навчання в ділових іграх спрямовується на формування комунікативних умінь, адже в умовах взаємодії з товаришами майбутні фахівці вчаться налагоджувати i підтримувати контакт, спрямовувати обговорення питань у потрібному напрямі, виробляти певний стиль стосунків. Крім того, у діловій грі у студентів розвиваються організаторські уміння: оптимально розподіляти 
роботу, організовувати роботу відповідно до запланованого, готувати проекти документації тощо. Участь в ділових іграх допомагає розвивати культуру прийняття рішень, виховує обмеження в емоційних проявах, стриманість у словах та вчинках.

Оскільки ділові ігри передбачають взаємодію учасників, то кожен з них, спостерігаючи за товаришами, отримує змогу ідентифікувати себе 3 іншими, отримати зворотній зв'язок при оцінюванні власних почуттів і поведінки. Зворотний зв'язок допомагає студентам оцінити свої професійні та особистісні настанови та поведінку. "Участь студентів у ділових іграх суттєво полегшує процес самопізнання та інтроспекції, оскільки здебільшого вони знають, чого хочуть як майбутні фахівців, але для максимальної самореалізації потрібна співучасть інших студентів, прийняття їх групою, що також створить умови для ефективного саморозкриття" $[5,125]$.

Відтак ділові ігри можна використовувати для формування професійних мотивів та інтересів, розвитку системного мислення майбутнього фахівця, передачі цілісного уявлення про майбутню професійну діяльність, виховання відповідального ставлення до виконуваних професійних обов'язків, самопізнання студентів тощо.

Значна ефективність ділових ігор досягається не лише завдяки максимально повному відтворенню реальних умов професійної діяльності, але й завдяки повному включенню студента в ігрову ситуацію, інтенсифікації міжособистісного спілкування, наявності яскравих емоційних переживань.

Характерними ознаками ділових ігор є:

a) наявність проблеми, мети і завдань;

б) скорочення тривалості часу на засвоєння професійних умінь, формування умінь та навичок;

в) розподіл та розігрування ролей;

г) наявність ситуацій, що послідовно розв'язуються, кількох ситуацій, кількох етапів гри;

д) формування самостійних рішень студентів;

е) наявність системи стимулювання;

є) врахування можливих перешкод;

ж) об’єктивність оцінки результатів гри [4, 209].

О. Пасічник до ознак ділових ігор відносить такі:

а) наявність різних моделей спілкування, що становлять систему професійного спілкування майбутнього фахівця;

б) наявність ролей та їх розподіл між учасниками; в) відмінність цільових установок учасників гри, що виконують різні ролі;

г) рольова взаємодія;

д) наявність спільної мети в усієї групи студентів, що беруть участь у діловій грі;

е) альтернативність рішень та можливість діяти відповідно до умов конкретної ситуації;

$\epsilon)$ наявність системи групового та індивідуального аналізу результатів діяльності учасників групи під час ділової гри;

ж) можливість керувати емоційною напругою, що виникає під час ділової гри, понукаючи тим самим студентів до вибору адекватної комунікативної стратегії $[5,126]$.

До наведених можемо додати ще й такі ознаки:

a) тривалий час залучення студентів до навчального процесу;

б) можливість самостійного творчого пошуку розв'язання проблемної ситуації;

в) наявність примусової активації мислення студентів, яка ними часто не усвідомлюється.

До переваг ділових ігор належать такі:

1) гра дозволяє скоротити час на накопичення професійного досвіду;

2) гра володіє експериментаторським потенціалом, адже дає змогу апробувати різні стратегії розв'язання поставлених завдань;

3) у діловій грі знання засвоюються не для майбутнього застосування, не абстрактно, а в реальному для учасника процесі інформаційного забезпечення його ігрових дій, в динаміці розвитку сюжету ділової гри, у формуванні цілісного образу професійної ситуації;

4) гра дозволяє формувати у майбутніх фахівців цілісне уявлення про професійну діяльність в їі динаміці;

5) ділова гра дає змогу набути соціального досвіду у сфері комунікації, прийняття рішень тощо [2, 129-142].

Крім того, завдяки застосуванню ділових ігор підвищується інтерес до навчальних занять загалом і до тих проблем, які моделюються в їх процесі, зокрема, підвищується пізнавальна активність студентів. Надзвичайно важливо, що в процесі ділових ігор в майбутніх фахівців змінюється ставлення до тих конкретних ситуацій, які були предметом ділової гри, та до людей, які виконували у грі певні ролі. Цей аспект особливо актуальний для тих студентів, які обрали професію, покладаючись на чужу думку чи точку зору, або ж є недостатньо мотивованими, чи не мають достатніх уявлень (або ж мають викривлені уявлення) про майбутню професію. Відтак вони мають змогу по-новому глянути на 
обов'язки, які виконуватимуть, переоцінити майбутню професійну діяльність, сформувати мотивацію на її здобуття або ж відмовитися від подальшого опанування професією та переорієнтуватися на інші сфери діяльності.

Проте необхідно розуміти, що ефективність ділових ігор залежить від дотримання низки умов. Насамперед, важливо, щоб ігрова діяльність була включена у канву підготовки майбутніх фахівців впродовж усього періоду навчання, розвиваючись від простих до складних форм на різних етапах навчання. Ситуативне використання ділових ігор час від часу корисним не буде, більш того, за таких умов воно може принести більше шкоди, адже сприйматиметься студентами як розвага.

Важливо також забезпечувати комплексний характер ділових ігор для того, щоб вони сприяли інтеграції різних навчальних дисциплін. Ця умова $\epsilon$ очевидною, адже професійна діяльність носить синтетичний характер, синтезуючи різноманітні знання та уміння. Отже й у грі має відображатися ця риса майбутньої професійної діяльності студентів.

Не менш важливим $\epsilon$ забезпечення реалістичності змісту ділових ігор, коли вони будуються на основі реального практичного матеріалу конкретних установ, закладів, підприємств. Таким чином майбутні фахівці мають змогу спрогнозувати труднощі майбутньої професійної діяльності та розробити алгоритм їхнього подолання.

Для викладача як проектанта та користувача ділові ігри є достатньо трудомістким видом навчальних занять. Підготовка до їхнього проведення вимагає глибокого розуміння процесу навчання, психологічних особливостей студентів і водночас великих часових затрат. Проте їхня ефективність доводить ці затрати виправданими. Відтак для оптимізації процесу проектування та проведення ділових ігор викладач може скористатися порадами А. Вербицького [2]:

1) оскільки ділові ігри є ресурсозатратною формою навчання, варто застосовувати їх тоді, коли за допомогою інших форм і методів навчання досягнути навчального результату неможливо. Наприклад, використання ділових ігор виправдане у ситуаціях, коли необхідно отримати цілісний досвід виконання майбутньої професійної діяльності, а також соціальних взаємин, систематизувати вже наявні у студентів знання та вміння, сформувати професійне творче мислення;

2) ділова гра повинна відображати ті грані професійної діяльності, які вже відомі майбутнім фахівцям. Саме тому кожна гра потребує завчасної підготовки, а відтак перебудови всієї методики навчання, що використовується викладачем;

3) застосування ділової гри вимагає від викладача достатньої професійної майстерності, адже вона не повинна зводитися до простого тренування чи азартної розваги;

4) навчальна цінність гри залежить від рівня самостійності студентів у процесі іiї проведення. Тому основна робота викладача має проводитися на етапі розробки та підготовки гри, а також іiі оцінювання;

5) ділова гра передбачає більшу свободу дій студента, тому викладачу варто переглянути власні традиційні погляди на дисципліну в навчальній аудиторії;

6) оптимальна тривалість ділової гри - до чотирьох академічних годин.

Висновки. Отже, ділова гра як активний метод навчання володіє значним дидактичним потенціалом. 3 допомогою цього методу навчання можна формувати уміння, навички та професійно-значущі якості особистості майбутнього фахівця. Проте ефективність цього процесу залежить від того, як здійснюється організація і проведення гри та як мотиви закладаються в іiі основу викладачами.

\section{ЛІТЕРАТУРА}

1. Арутюнов Ю. С. О классификации методов активного обучения / Ю. С. Арутюнов, Н. В. Борисова, С. Г. Колесниченко // Межведомственная школасеминар по активным методам обучения "Применение активных методов обучения в учебном процессе": тезисы докладов. - Рига, 1983. - С. 21 - 24.

2. Вербицкий А. А. Активное обучение в высшей школе: контекстный подход: метод. пособие / А. А. Вербицкий. - М.: Высшая школа, 1991. -208 с.

3. Дяченко-Богун М. Активні методи навчання у вищому навчальному закладі / М. Дяченко-Богун // Витоки педагогічної майстерності. - 2014. - Вип. 14. C. 74-79.

4. Очеретна Н. Д. Особливості застосування ділових ігор у процесі вивчення іноземної мови у вищих навчальних закладах / Н. Д. Очеретна // Педагогічна освіта: теорія і практика. - 2013. - Вип. 14. - С. 206 210.

5. Пасічник О.О. Особливості використання ділових ігор на заняттях з іноземної мови уВНЗ / О. О. Пасічник // Науковий вісник Ужгородського університету: Серія: Педагогіка. Соціальна робота / гол. ред. І.В. Козубовська. - Ужгород: Говерла, 2014. - Вип. 30. - С. 125-127.

6. Хоменко О. О. Навчальні ділові ігри як засіб формування професійних умінь студентів технікумів і коледжів (на прикладі будівельних спеціальностей) : автореф. дис. ... канд. пед. наук / О. О. Хоменко. - К., 1994. $-34 \mathrm{c}$. 


\section{REFERENCES}

1.Arutyunov, Yu. S., Borisova, N.V. andKolesnichenko, S. G. (1983). O klassifikatsii metodov aktivnogo obucheniya [On the classification of active learning methods]. Interagency school-seminar on active teaching methods "Application of active teaching methods in the learning process", Riga, pp. 21 - 24. [in Russian].

2. Verbitskiy, A. A. (1991). Aktivnoe obuchenie v vyisshey shkole: kontekstnyiy podhod [Active learning in higher education: contextual approach]. Moscov, Vyisshaya shkola, 208 p. [in Russian].

3. Dyachenko-Bogun, M. (2014). Aktyvni metody navchannya $\mathrm{u}$ vyshhomu navchalnomu zakladi [Active teaching methods at a higher educational institution]. Origins of pedagogical skill, vol. 14, pp. $74-79$. [in Ukrainian].

4. Ocheretna, N. D. (2013). Osoblyvosti zastosuvannya dilovyx igor $u$ procesi vyvchennya inozemnoyi movy u vyshhyx navchalnyx zakladax [Features of the use of business games in the process of learning a foreign language in higher education]. Pedagogical Education: Theory and Practice, vol. 14, pp. 206 - 210. [in Ukrainian].

5. Pasichnyk, O.O. (2014). Osoblyvosti vykorystannya dilovyx igor na zanyattyax z inozemnoyi movy u VNZ [Features of the use of business games in foreign language classes at universities]. Scientific herald of Uzhhorod University: Series: Pedagogy. Social work, Uzhgorod, Goverla, vol. 30, pp. 125-127. [in Ukrainian].

6. Xomenko, O. O. (1994). Navchalni dilovi igry yak zasib formuvannya profesijnyx umin studentiv texnikumiv i koledzhiv (na prykladi budivelnyx specialnostej) [Educational business games as a means of forming professional skills of students of technical schools and colleges (for example, construction specialties)]. Extended abstract of candidate's thesis. Kyiv, 34 p. [in Ukrainian].

Стаття надійшла до редакції 18.10.2018

УДК 371.13:796

DOI:

Олександр Солтик, кандидат наук з фізичного виховання $і$ спорту, доцент, завідувач кафедри теорії $і$ методики фізичного виховання $і$ спорту Хмельницького національного університету

\section{ФОРМУВАННЯ ПРОФЕСІЙНОЇ НАДІЙНОСТІ МАЙБУТНЬОГО ВЧИТЕЛЯ ФІЗИЧНОї КУЛЬТУРИ}

У статті розглядається проблема формування професійної надійності майбутніх вчителів фізичноі культури. Окрема увага приділена дослідженню стану сформованості професійной надійності майбутніх діючих вчителів фізичної культури. Дослідження діючих вчителів дозволило побудувати модельні характеристики, встановити критерії і шкалу оиінювання показників професійної надійності. Важливим механізмом покращення формування професійної надійності майбутнього вчителя фізичної культури виступає реалізація педагогічних умов в освітньому процесі, функціонування педагогічної системи формування надійності, застосування окремих методів і методик формування надійністних характеристик.

Ключові слова: професійна надійність; майбутній вчитель; формування професійної надійності, вчитель фізичної культури.

Jim. 6.

Oleksandr Soltyk, Ph.D. (Physical Education and Sport), Associate Professor, Head of the Theory and Methods of Physical Education and Sport Department Khmelnytskiy National University

\section{FORMATION OF PROFESSIONAL RELIABILITY OF FUTURE TEACHERS OF PHYSICALEDUCATION}

The article deals with the formation of professional reliability of future teachers of physical education. Elaboration of personal notion, determination of the content and a structure of the analyzed issue served as a premise for analysis of professional reliability of future teachers.

Special attention is paid to analysis of the level of formation of professional reliability of future and active teachers of physical education. An analysis of active teachers allowed constructing model characteristics, define criteria and scale of assessment of indices of professional reliability. Significant discrepancies by all indices that characterize reliability of future and active teachers have been revealed with experimental means.

Revealing lagging aspects of professional reliability of future teachers of physical education allows defining the priority areas with the purpose of their improvement within professional training.

An important mechanism of improvement of formation of professional reliability of future teachers of physical education is realization of pedagogical conditions within educational process, functioning of pedagogical system of reliability formation, application of individual means and methods of formation of personal characteristics. 